\title{
Kampung Tangguh: Wujud Kolaborasi antar-Stakeholder dalam Merespons Pandemi COVID-19
}

\author{
Yusrin Rahmawati ${ }^{1}$, Farah Fadillah Anugrah ${ }^{2}$, Erva Mutiara Hati ${ }^{3}$, Ali Roziqin ${ }^{4}$
}

\begin{abstract}
Abstrak
Kolaborasi dalam penanganan pandemi COVID-19 sangat dibutuhkan, terutama dalam menangani permasalahanpermasalahan yang muncul. Penelitian ini mencoba untuk menemukan bentuk kolaborasi antar aktor dalam Program Kampung Tangguh. Selain itu, penelitian ini bertujuan untuk mengelaborasiakan peran antar stakeholder dalam merespons pandemi COVID-19, melihat konteks Program Kampung Tangguh Semeru. Menggunakan teori kebencanaan dan konsep terkait desa, penelitian ini berargumen bahwa kunci kesuksesan berjalannya Program Kampung Tangguh Semeru di Jawa Timur merupakan hasil partisipasi dari bawah (bottom up participation) atau bentuk partisipasi masyarakat dan pemerintah dalam menghadapi pandemi COVID-19. Dalam penulisan artikel, peneliti menggunakan pendekatan analisis deskriptif, yang didasarkan pada studi pustaka atau bersumber dari data sekunder.
\end{abstract}

Kata Kunci: Pandemi, Kolaborasi, Kampung Tangguh

\begin{abstract}
Collaboration in handling COVID-19 pandemic is urgently needed, especially in handling problems that arise from it. This research is try to find collaboration between stakeholders within Tough Village Program (Program Kampung Tangguh). In addition, this study aims to elaborate on the roles between stakeholders in responding to the COVID-19 pandemic. Using disaster theory and concept about village, this research argues that the key to the success of the Tangguh Semeru Village Program in East Java is through bottom up participation or a form of community participation in the government in facing the COVID-19 pandemic. In writing this article using a descriptive analysis approach, which is based on literature study or sourced from secondary data.
\end{abstract}

Keywords: Pandemic, Collaboration, Tough Village

\section{Pendahuluan}

Kolaborasi ialah sebuah interaksi atau kompromi antar beberapa elemen, lembaga dan atau pihak-pihak yang terlibat secara langsung dan tidak langsung yang menerima akibat dan manfaatnya. Nilai yang menjadi landasan utama adanya kolaborasi yaitu tujuan yang sama, kesamaan persepsi, kemauan untuk berproses, saling memberikan manfaat, kejujuran, kasih sayang serta berbasis masyarakat (Haryono, 2012). Kolaborasi dalam penanganan kasus COVID-19 sangat dibutuhkan dimulai dari komitmen yaitu berupa regulasi peraturan perundangan yang menjadi bahan dalam melangkah. Konsep Collaborative Governance dijadikan sebagai langkah alternatif dalam penanganan kasus COVID-19 yang diharapkan mampu mewujudkan percepatan dan implementasi dari penanganan COVID-19 yang melibatkan berbagai pihak (Rivelino \& Ginting, 2020).

Tahun 2020 menjadi tahun krisis bagi seluruh negara di dunia akibat dari adanya pandemi COVID-19 (Phan \& Nguyen, 2020). COVID-19 sendiri merupakan virus baru yang tingkat penularannya relatif cepat dengan tingkat kematian yang cukup tinggi (Susilo et al., 2020). Hingga saat ini belum ditemukan

\footnotetext{
${ }^{1}$ Program Studi Ilmu Pemerintahan, Fakultas Ilmu Sosial dan Ilmu Politik, Universitas Muhammadiyah Malang (email korespondensi: yusrinrahma99@gmail.com)

${ }^{2}$ Program Studi Ilmu Pemerintahan, Fakultas Ilmu Sosial dan Ilmu Politik, Universitas Muhammadiyah Malang (email: farahfadillah1999@gmail.com)

${ }^{3}$ Program Studi Ilmu Pemerintahan, Fakultas Ilmu Sosial dan Ilmu Politik, Universitas Muhammadiyah Malang (email: ervamutiara01@gmail.com)

${ }^{4}$ Program Studi Ilmu Pemerintahan, Fakultas Ilmu Sosial dan Ilmu Politik, Universitas Muhammadiyah Malang (email: ali_roziqin@ymail.com)
} 
Yusrin Rahmawati, Farah Fadillah Anugrah , Erva Mutiara Hati, Ali Roziqin - Kampung Tangguh: Wujud Kolaborasi antar-Stakeholder dalam Merespons Pandemi COVID-19

terapi definitif yang tepat untuk mengobati virus ini (Whitworth, 2020). Maka dari itu virus ini tidak dapat dianggap remeh meskipun pada tahun 1960, COVID-19 dianggap sebagai penyebab flu biasa (Al-Osail \& Al-Wazzah, 2017). Penyebaran yang cukup signifikan dan cenderung masif sudah dirasakan oleh seluruh dunia, termasuk Indonesia. Kasus pertama COVID-19 di Indonesia terkonfirmasi pada tanggal 2 Maret 2020 (Mukaromah, 2020).

Penyebaran virus yang sangat pesat membawa dampak pada banyak aspek kehidupan manusia di dunia. Setiap individu dituntut atau bahkan dipaksa untuk bertransformasi dan beradaptasi dengan kondisi baru yaitu konsep yang tengah berjalan ini. Mulai dari melakukan swakarantina secara sukarela, menerapkan social distancing atau physical distancing, hingga masyarakat dituntut merubah pola hidup yang bersih dibandingkan sebelum adanya pandemi COVID-19. Selain itu banyak aktivitas kerja, agenda rapat, dan sistem pembelajaran yang semula dilakukan secara tatap muka kini dialihkan ke media daring yang artinya hal ini menjadi hal baru yang tidak biasa dilakukan sebelumnya. Selain itu juga berdampak pada meningkatnya karyawan yang terkena PHK, kerawanan pangan, dan meningkatnya jumlah kriminalitas.

Jumlah kasus terkonfirmasi positif virus COVID-19 pada bulan April 2020 secara keseluruhan di Jawa Timur telah mencapai 662 kasus. Dari kasus tersebut terdapat 127 orang yang sembuh, 66 orang meninggal dan 469 orang yang masih dirawat. Gubernur Jawa Timur mengatakan bahwa jumlah total sembuh yang ada sebanyak 127 orang tersebut merupakan persentase tertinggi di Indonesia, yakni mencapai 19,18\%. Untuk meninggal ada 66 orang dengan persentase 9,97\%. Dari data yang diterima, 469 pasien positif COVID-19 di antaranya dirawat di rumah (168 orang), di gedung (31 orang) dan di rumah sakit (270 orang) (Azmi, 2020). Sedangkan untuk Pasien Dalam Pengawasan (PDP) di Jawa Timur terdapat 2.411 orang. Dari angka tersebut, ada 1.251 PDP yang masih diawasi, 964 PDP telah selesai masa pengawasan serta 196 PDP meninggal dunia. Untuk jumlah pasien yang masih diawasi sendiri yakni mencapai 1.251 PDP masing-masing dirawat di rumah sakit ada 819 orang, isolasi di rumah 428 orang serta di gedung ada 4 orang (Azmi, 2020). Sedangkan untuk Orang Dalam Pemantauan (ODP) di Jawa Timur terdapat 17.625 orang. Dengan rincian 6.156 ODP masih dipantau, 11.424 ODP selesai dipantau, dan 45 ODP meninggal dunia. 6.156 ODP yang dipantau di antaranya 5.813 ODP di rumah, 340 ODP di rumah sakit dan 3 ODP di gedung (Azmi, 2020). Secara keseluruhan untuk total kasus COVID-19 di Jawa Timur baik positif, PDP dan ODP ada 20.698 kasus. Untuk pasien sembuh terkait kasus COVID-19 di Jawa Timur ada 12.515 orang. Untuk kasus kematian terkait kasus COVID-19 di Jawa Timur ada 307 orang. Sejauh ini total 34 kabupaten/kota di Jawa Timur telah terserang wabah COVID-19 namun masih ada 4 wilayah yang belum memiliki kasus positif COVID-19 yakni Sampang, Sumenep, Ngawi, dan Kota Mojokerto (Azmi, 2020).

Dari kasus penyebaran COVID-19 yang terjadi di Jawa Timur dapat dikatakan bahwa pada dasarnya pemerintah tidak akan dapat menghindari kematian akibat virus corona dan dampak ekonomi dari penyebaran virus ini (Anderson et al., 2020). Namun pemerintah tetap memiliki kewajiban untuk memaksimalkan segala upaya dalam menjaga masyarakatnya dari wabah COVID-19 melalui berbagai kebijakan yang dikeluarkan. Wujud kolaborasi yang dilakukan oleh pemerintah yaitu melaui Program Kampung Tangguh yang dikampanyekan oleh Kapolda Jawa Timur untuk mendisiplinkan masyarakat akan pentingnya protokol kesehatan dalam pencegahan dan memutus mata rantai penyebaran virus COVID-19 yang diupayakan dengan membentuk Community Policing di tengah masyarakat melalui program yang berbasis problem solving. Program tersebut telah diluncurkan di beberapa daerah di Jawa Timur bahkan di Indonesia. Mengingat kasus COVID-19 di Jawa Timur menduduki tingkat tertinggi setelah DKI Jakarta. Maka dari itu upaya kolaborasi melalui program Kampung Tangguh memiliki peran yang penting.

Dengan adanya implementasi melalui kolaborasi diharapkan masyarakat nantinya mampu menghadapi permasalahan secara lebih mandiri pada permasalahan yang terjadi secara dinamis sehingga prinsip-prinsip good governance dapat diwujudkan. Kerja sama antar stakeholders (pemerintah, masyarakat, dan swasta) dalam mewujudkan kekuatan dan pertahanan dalam menghadapi pandemi utamanya di Indonesia. Karena, dengan adanya kolaborasi yang dilakukan antara Gubernur 
Jawa Timur dengan Forkopimda yakni Polda Jatim dan Kodam V Brawijaya tersebut dinilai sukses dalam menekan angka persebaran Virus COVID-19. Kolaborasi yang tengah dijalankan antar stakeholder yang memberikan hasil positif terhadap upaya menghadapi pandemi sebagai bentuk dari bottom-up participation (partisipasi dari bawah) atau bentuk partisipasi masyarakat terhadap pemerintah dalam menangani permasalahan global yang sedang terjadi tersebut. Dari pemaparan yang telah dijelaskan diatas menjelaskan bahwa peran dari tiga stakeholders tersebut tidak dapat dipisahkan sebab ketiganya memiliki keterkaitan peran yang sangat penting dalam mewujudkan tata kelola pemerintahan yang baik (Mashuri et al., 2020).

Jawa Timur juga siap menjadi role model karena program Kampung Tangguh Semeru Benteng di Kelurahan/Kecamatan Mayangan Kota Probolinggo menjadi program Kampung Tangguh terbaik di Jawa Timur (Susilo, 2020) karena memiliki berbagai bentuk inovasi dan ide yang dapat memajukan perekonomian, disiplin terhadap aturan atau himbauan pemerintah untuk menjalankan protokol kesehatan, mempersiapakan terkait adanya UKM, hingga peningkatan kualitas dalam pelayanan perekonomian (Arifin, 2020). Dari sini dapat dilihat bahwa desa merupakan objek yang memiliki peran begitu penting karena desa atau kampung sebagai benteng pertahanan terakhir dalam upaya mencegah penyebaran COVID-19 dan desa memiliki peluang yang sangat besar dalam hal mendisiplinkan masyarakatnya untuk mematuhi protokol kesehatan dan mengembangkan perekonomian masyarakat. Dengan kondisi semacam ini masyarakat memiliki tuntutan untuk tetap memenuhi kebutuhan dengan bekerja secara mandiri memanfaatkan sumber daya yang ada.

Desa dijadikan sebagai benteng pertahanan ketika Indonesia berada dalam kondisi krisis seperti yang saat ini sedang terjadi. Desa sangat berhubungan dengan entitas sosial. Oleh karena itu, ketangguhan sebuah desa dalam membentengi dari dari pandemi menentukan bagaimana sebuah kebijakan mampu terealisasikan dengan baik. Ketangguhan sosial yang mampu memanfaatkan keberagaman sosial dapat saling menopang dan membangun pilar bersama, berbasis pada kesadaran kolektif serta perlu dirawat bersama agar tidak mengalami keterperosokan sosial. Entitas sosial terhadap ketangguhan suatu desa akan diuji jika ekosistem menunjukan perubahan yang cukup signifikan serta berpengaruh terhadap masyarakat itu sendiri. Selain itu pandemi ini juga memberi dampak pada Indonesia terkait divisit kreatifitas atau inovasi keberagaman sosial. Pandemi ini juga telah memberikan gambaran yang cukup jelas bagaimana sistem sosial bangsa Indonesia mampu bekerja, baik mulai dari ranah politik, sosial, ekonomi, maupun lingkungan.

Penelitian terdahulu terkait Kampung Tangguh sebagai upaya untuk memutus mata rantai penyebaran COVID-19 memperlihatkan, dalam upaya pencegahan penyebaran COVID-19 sangat dibutuhkan peran serta antara pemerintah, swasta, dan masyarakat. Kolaborasi tiga stakeholders tersebut termasuk dalam praktek paradigma good governance. Kerja sama dari ketiga pilar tersebut sangat penting adanya sebagai bentuk upaya dalam pencegahan penyebaran COVID-19 (Mashuri et al., 2020). Program Kampung Tangguh dan kolaborasi antar stakeholder tersebut mampu meningkatkan kesadaran kalangan masyarakat agar pandemi ini segera berakhir, masyarakat menjadi lebih patuh terhadap semua aturan atau himbauan yang diberikan oleh pemerintah, dan yang paling utama adalah mampu meningkatkan angka perekonomian yang anjlok akibat adanya pandemi dan setelah adanya pandemi. Dapat disimpulkan bahwa melalui inovasi program inilah yang nantinya menuntun masyarakat dalam menyalurkan kemampuan kreatifitas serta aspirasi yang dimiliki yang dapat dijadikan motivasi untuk mengembalikan perekonomian di Indonesia. Tujuan dari penulisan artikel ini yaitu untuk mengelaborasiakan peran antar stakeholder dalam merespons pandemi COVID-19. Kebijakan yang baik saja tidak cukup dalam upaya menangani COVID-19 di negeri ini. Selain itu, dibutuhkan adanya komitmen masyarakat untuk mematuhi segala aturan dan kebijakan pemerintah. Kepatuhan masyarakat sendiri hanya akan muncul apabila masyarakat memiliki belief system yang sama dengan pemerintah (Harihah \& Rizaldi, 2020).

\section{Kerangka Teori}

Dalam penulisan artikel ini, penulis menggunakan dasar konsep yang berkaitan dengan kebencanaan dan desa. Teori bencana yang dimaksudkan adalah teori bencana non- 
alam. Bencana merupakan suatu rangkaian peristiwa yang mampu menganggu atau mengancam kehidupan manusia, baik disebabkan oleh faktor alam, faktor non-alam, maupun faktor manusia. Sehingga mengakibatkan timbulnya korban jiwa, kerusakan lingkungan, kerugian harta benda, dan dampak psikologis (Darmawan, 2019). Sedangkan bencana non-alam sendiri merupakan bencana yang diakibatkan peristiwa atau rangkaian peristiwa non-alam yakni berupa gagal teknologi, gagal modernisasi, epidemi, dan wabah penyakit (Darmawan, 2019). Penyebaran COVID-19 yang sedang melanda saat ini dapat dikatakan sebagai suatu bencana non-alam bagi seluruh negara di dunia karena diakibatkan oleh peristiwa atau rangkaian peristiwa berupa wabah penyakit yang menyebar keberbagai negara di dunia hingga WHO mengatakan COVID-19 sebagai Pandemi.

Masifnya penyebaran COVID-19 telah memberikan dampak yang signifikan di berbagai aspek kehidupan manusia, tak terkecuali di desa yang berperan sebagai benteng terakhir pertahanan. Secara etimologi kata desa berasal dari bahasa Sansekerta, desa yang berarti tanah air, tanah asal, atau tanah kelahiran. Dari perspektif geografis, desa atau village diartikan sebagai "a groups of hauses or shops in a country area, smaller than a town". Desa merupakan kesatuan masyarakat hukum yang mana memiliki kewenangan untuk mengurus rumah tangganya sendiri yang di dasarkan pada hak asal-usul atau adat istiadat dan telah diakui dalam pemerintah nasional serta berada di daerah kabupaten (Barniat, 2019). Dapat disimpulkan bahwa Desa merupakan self community, yaitu komunitas yang mengatur dirinya sendiri. Artinya, desa juga memiliki kewenangan dalam mengurus serta mengatur kepentingan masyarakatnya dengan menyesuaikan kondisi sosial dan budaya. Dengan demikian, posisi desa yang memiliki otonomi asli sangat strategis sehingga memerlukan perhatian yang seimbang terhadap penyelenggaraan Otonomi Daerah.

Untuk itu, upaya desa dalam memitigasi bencana non alam COVID-19 yang berperan sebagai benteng pertahanan terakhir sangat dibutuhkan. Mitigasi sendiri yaitu suatu rangkaian atau upaya yang dilakukan bersamasama dalam rangka mengurangi resiko akibat adanya bencana, baik melalui pembangunan fisik maupun penyadaran dan peningkatan kemampuan menghadapi ancaman bencana
(Sunarti, 2018). Dalam hal ini, kolaborasi dalam penanggulangan COVID-19 menjadi solusi yang sangat tepat karena melalui program Kampung Tangguh Semeru inilah salah satu upaya desa melakukan mitigasi terhadap penyebaran COVID-19 dapat dilakukan.

\section{Metode Penelitian}

Penulisan arikel ini menggunakan pendekatan analisis deskriptif dari studi pustaka atau bersumber dari data sekunder. Data sekunder merupakan data yang diperoleh melalui artikel atau jurnal nasional maupun internasional yang terakreditasi, dokumen atau laporan resmi dari instansi pemerintah dan media online yang relevan dengan Kampung Tangguh. Studi pustaka merupakan suatu metode pengumpulan data yang mana diarahkan kepada pencarian data dan informasi melalui dokumen-dokumen, baik dokumen tertulis, foto-foto, gambar, maupun dokumen elektronik yang dapat mendukung dalam proses penulisan. Peneliti menggunakan 20 jurnal terkait dengan "COVID-19”, "Kampung Tangguh", “Desa”, dan “Kolaborasi” yang diperoleh dari Google Scholar. Langkah pertama yang dilakukan penulis yaitu mencari literatur yang diperoleh dari Google Scholar dengan kata kunci Kampung Tangguh dan COVID-19. Studi kepustakaan sendiri dilakukan dengan penelaahan dan pengutipan berbagai teori yang relevan. Selanjutnya, dilakukan pula pencarian studi-studi sebelumnya yang membahas tentang Kampung Tangguh dan dilanjutkan dengan perbandingan serta pengecekan kembali derajat kepercayaan suatu informasi yang didapat sebelum data tersebut dianalisis. Analisis dilakukan untuk memberikan penjelasan lebih mendalam mengenai fenomena yang diteliti.

\section{Hasil}

Munculnya pandemi COVID-19 di Indonesia mendesak pemerintah pusat dan pemerintah daerah menerbitkan kebijakan-kebijakan baru yang dapat meminimalisir angka positif COVID-19yang telah berdampak pada kehidupan masyarakat. Pada kenyataannya, pemerintah tidak dapat menghindari kematian dari dampak adanya virus corona dan dampak ekonomi dari penyebaran Virus COVID-19 (Anderson et al., 2020). Pemerintah dituntut untuk dapat menjalankan kewajiban serta upaya yang telah dibuat dalam menjaga masyarakat dari sebaran COVID-19. Oleh karena pemerintah 
telah menciptakan berbagai kebijakan untuk meminimalisir persebaran virus tersebut. Sesuai dengan model kelembagaan, pada dasarnya pemerintah memiliki tugas pokok yaitu sebagai pembuat suatu kebijakan. Oleh karena itu dapat dikatakan bahwa semua hal yang berurusan dengan pemerintah maka dapat disebut sebagai kebijakan publik. Perlu diketahui bahwa kebijakan publik merupakan wewenang atau tugas yang dimiliki dan harus dilaksanakan oleh pemerintah sebagai pelaku pembuatan kebijakan (Harihah \& Rizaldi, 2020). Dengan adanya permasalahan global yaitu COVID-19 tersebut pemerintah dituntut untuk dapat bergerak dengan cepat dan memberikan tindakan nyata yang diharapkan masyarakat dapat memberikan solusi dalam menangani ancaman COVID-19 yaitu melalui produk hukum turunan yang ada di Indonesia.

Terdapat lima Peraturan Pemerintah dan sebelas Peraturan Menteri Kesehatan yang diharapkan sebagai kepastian hukum dalam pelaksanaan UU No 6 Tahun 2018 tentang Kekarantinaan (Telaumbanua, 2020). Berbagai macam upaya yang telah dibuat oleh pemerintah Indonesia dalam meminimalisir angka persebaran COVID-19, di antaranya adalah pembentukan Gugus Tugas Percepatan Penanganan COVID-19 yang telah disahkan melalui Keputusan Presiden RI No 7 Tahun 2020. Lalu diperbaharui melalui Keputusan Presiden RI No 9 Tahun 2020. Pembentukan Gugus Tugas tersebut bertujuan untuk meningkatkan ketahanan nasional di bidang kesehatan serta meningkatkan sinergi antara kementerian atau lembaga serta pemerintah daerah. Di setiap daerah dibentuk gugus tugas agar dapat mengantisipasi eskalasi penyebaran virus di tiap daerah. Sehingga daerah tersebut dapat menyiapkan solusi atau upaya dalam mencegah serta mendeteksi dan merespons adanya penyebaran Virus COVID-19. Pemerintah juga membuat kebijakan baru yang dapat membantu masyarakat terhindar dari Virus COVID-19 yaitu berupa kebijakan Pembatasan Sosial Berskala Besar (PSBB). Tujuan adanya kebijakan PSBB tersebut mengurangi serta memutus mata rantai penyebaran Virus COVID-19. Kebijakan tersebut dijalankan karena telah mendapat persetujuan dari Menteri Kesehatan serta mengikuti pedoman PSBB yaitu sesuai dengan Peraturan Menteri Kesehatan Nomor 9 Tahun 2020 (Ulya, 2020).
Kebijakan pemerintah daerah terkait dengan percepatan Penanganan COVID-19 antara lain (a) Peraturan Menteri Dalam Negeri No 20 Tahun 2020 terkait dengan Percepatan Penanganan COVID-19 di Lingkungan Pemerintah Daerah (b) Peraturan Bersama Menteri Dalam Negeri dan Menteri Keuangan Nomor 119/2813/SJ tentang Percepatan Penyesuaian Anggaran Pendapatan dan Belanja Daerah Tahun 2020 dalam Rangka Penanganan COVID-19 Serta Pengamanan Daya Beli Masyarakat dan Perekonomian Nasional (c) Surat Edaran No. 440/2622/SJ tentang Pembentukan Gugus Tugas Percepatan Penanganan COVID-19 Daerah (d) Instruksi Menteri Dalam Negeri Nomor 1 Tahun 2020 dan (e) Buku Pedoman Umum dalam menghadapi Pandemi COVID-19 bagi Pemerintah Daerah atau yang dapat disebut sebagai buku saku. Dengan adanya buku saku tersebut dinilai dapat dijadikan sebagai media informasi dan valid terkait dengan pandemi COVID-19 dan informasi terkait upaya mencegah virus tersebut. Selain itu dengan adanya buku saku tersebut diharapkan dapat meningkatkan pengetahuan dan pemahaman masyarakat agar dapat menerapkan kebiasaan baru di masa pandemi saat ini.

Pemerintah juga melibatkan stakeholders dalam menangani pandemi COVID-19 melalui adanya Program Kampung Tangguh Semeru yang ada di Jawa Timur. Namun program tersebut sudah ada sejak dulu, hal tersebut dapat dibuktikan melalui adanya Program Kampung Tangguh di wilayah lainnya yang diciptakan untuk meningkatkan partisipasi masyarakat agar dapat bekerjasama dengan pemerintah untuk memutus mata rantai penyebaran COVID-19. Oleh karena itu program tersebut dapat dijalankan dalam jangka waktu yang cukup lama. Program Kampung Tangguh Semeru yang ada di Jawa Timur tersebut terus menerus dikampanyekan agar dapat meningkatkan kesadaran masyarakat dalam menghadapi pandemi. Hal tersebut dilakukan karena desa dijadikan sebagai benteng terakhir pertahanan yang dinilai efektif dalam memutus penyebaran mata rantai COVID-19. Selain itu program ini dibuat agar dapat meningkatkan kedisplinan masyarakat dalam menaati protokol kesehatan serta meningkatkan jiwa gotong royong masyarakat untuk saling membantu antar masyarakat yang terkenda dampak COVID-19. Upaya stakeholders dalam membantu 
Yusrin Rahmawati, Farah Fadillah Anugrah , Erva Mutiara Hati, Ali Roziqin - Kampung Tangguh: Wujud Kolaborasi antar-Stakeholder dalam Merespons Pandemi COVID-19

masyarakat yaitu dengan cara menyediakan UKM dan layanan ekonomi (menyediakan makanan dan sembako), pemberdayaan masyarakat dalam menciptakan masker dan faceshield secara mandiri. Dengan begitu masyarakat dapat membuktikan bahwa desa dapat dijadikan sebagai benteng pertahanan terakhir, sebab desa tersebut dapat mengatasi permasalahan dan memenuhi kebutuhan secara mandiri. Dapat disimpulkan bahwa program Kampung Tangguh Semeru ini telah diasopsi secara nasional dan disebut sebagai Kampung Tangguh Nusantara. Hal tersebut karena adanya antusias masyarakat dalam memutus mata rantai penyebaran COVID-19.

Keberhasilan Program Kampung Tangguh membuat pemerintah daerah yang lain ikut berbondong-bondong untuk menciptakan inovasi baru dalam penerapan Program Kampung Tangguh tersebut. Hal tersebut karena inovasi yang dibuat oleh aparat pemerintah dinilai berhasil dalam mengatasi permasalahan persebaran COVID-19. Selain itu anggota Polri terus memberikan pengetahuan serta pemahaman terkait inovasi tersebut yang dapat memberikan contoh terhadap desa atau kampung yang lainnya. Adanya kolaborasi antara masyarakat dengan aparat pemerintah merupakan elemen penting dalam menekan angka persebaran COVID-19 di Indonesia. Seperti Inovasi yang telah dibuat oleh Polda Jawa Timur yaitu Program Kampung Tangguh Semeru, program tersebut direalisasikan dengan cara memberikan sosialisasi atau pengetahuan kepada masyarakat terkait dengan pemberantasan COVID-19 yang dimulai dari desa atau kampung. Sosialisasi tersebut dilakukan di Jawa Timur karena Jawa Timur tercatat menduduki posisi pertama sebagai angka penyebaran tertinggi di Indonesia. Oleh karena itu pembentukan Program Kampung Tangguh Semeru tersebut ditetapkan pada saat adanya penerapan kebijakan Pembatasan Sosial Berskala Besar (PSBB) di wilayah Surabaya Raya (Surabaya, Sidoarjo, Gresik) dan Malang Raya (Kabupaten Malang, Kota Malang, dan Kota Batu).

Program Kampung Tangguh tersebut membantu masyarakat mengatasi permasalahan persebaran COVID-19 yang dimulai dari RT/ RW. Contoh Kampung Tangguh lainnya ada di daerah Kalimantan Selatan yang disebut sebagai "Kampung Tangguh Banua" yang dibuat secara langsung oleh Polda Kalimantan Selatan. Program tersebut berhasil menerapkan kampung tangguh di 67 kampung atau desa yang tersebar di 13 kabupaten. Sesuai dengan informasi yang telah didapatkan, Kalimantan Selatan juga memiliki catatan penyebaran COVID-19 yang tinggi. Dengan adanya informasi tersebut pemerintah desa membuat peraturan jika akan memasuki kampung atau desa tersebut masyarakat wajib mematuhi protokol kesehatan. Kepatuhan masyarakat dalam menjalankan aturan yang telah ditetapkan oleh pemerintah tersebut, Kapolda Irjen Pol Nico Afinta berpendapat bahwa telah tercatat sebanyak lima Kampung Tangguh Banua yang dapat dijadikan sebagai contoh untuk kampung yang lainnya. (Erfinanto, 2020).

Terdapat juga Inovasi yang diciptakan oleh Polda Nusa Tenggara Barat (NTB) yang disebut sebagai Desa Pantang Mundur (Lewu Isen Mulang). Kapolda Kalteng Irjen Pol Dedi Prasetyo mengutarakan bahwa nama desa tersebut memiliki makna yaitu ketangguhan dan keuletan masyarakat Suku Dayak dalam menghadapi tantangan dan dinamika pembangunan di wilayah tersebut. Inovasi tersebut dinilai dapat meningkatkan semangat dan partisipasi masyarakat dalam menghadapi Virus COVID-19. Selain itu Polda Nusa Tenggara Barat (NTB) juga mendirikan sebuah kampung yang dikenal sebagai "Kampung Sehat". Kampung tersebut dibentuk guna menumbuhkan partisipasi masyarakat dalam menyelesaikan permasalahan penyebaran COVID-19. Sebutan Kampung Sehat tersebut dibuat untuk menciptakan kampung yang steril, produktif secara ekonomi, asri, dan tangguh. Dalam menyukseskan program tersebut tentu ada campur tangan masyarakat dengan berbagai pihak yang saling berkaitan sehingga hal tersebut membuat masyarakat mampu menerapkan protokol kesehatan dan menciptakan emphaty building dan social bonding (Erfinanto, 2020). Terbentuknya berbagai macam bentuk serta konsep terciptanya kampung tangguh tersebut memiliki tujuan memutus mata rantai penyebaran COVID-19. Selain itu, program tersebut menjadi pedoman masyarakat agar berkesadaran hidup sehat dan selalu menjaga keamanan dan ketertiban di seluruh wilayah terutama di Jawa Timur. Program tersebut juga dinilai memiliki kelebihan dalam meningkatkan kesadaran masyarakat mentaati peraturan. Pada dasarnya seluruh 
kebijakan yang telah dibuat oleh pemerintah pasti akan berdampak pada proses penanganan COVID-19 di Indonesia. Akan tetapi pada kenyataanya kebijakan yang telah dibuat harus diimbangi dengan adanya komitmen masyarakat mematuhi seluruh bentuk aturan atau kebijakan yang telah dibuat dan ditetapkan pemerintah. Oleh karena itu kepatuhan masyarakat akan muncul jika masyarakat memiliki belief system yang sama dengan pemerintah (Harihah \& Rizaldi, 2020). Program Kampung Tangguh dapat direalisasikan secara maksimal karena pada dasarnya Kampung Tangguh tersebut dibentuk dengan berbasis komunitas warga sekitar dan melibatkan semua warga tanpa terkecuali. Perlu adanya kolaborasi antar stakeholder dalam memutus mata rantai penyebaran COVID-19. Kapolda Jatim Irjen Pol M Fadil Imran mengkampanyekan kepada masyarakat untuk tetap disiplin dan menerapkan protokol kesehatan dalam mencegah Virus COVID-19 dengan cara membentuk Community Policing di tengah masyarakat melalui program Kampung Tangguh Semeru Berbasis Problem Solving. Hal tersebut karena Kampung Tangguh Seemeru merupakan salah satu program unggulan Polda Jawa Timur yang dapat dijadikan masyarakat sebagai upaya dalam melawan penyebaran COVID-19 yang dilakukan mulai dari lingkup terkecil yaitu desa dan warga sekitar.

Pemerintah Provinsi Jawa Timur berkolaborasi dengan Forkopimda yang juga bekerjasama dengan Polda Jawa Timur dan Kodam V Brawijaya untuk menciptakan Program yaitu Kampung Tangguh yang bertujuan untuk dapat meminimalisir angka penyebaran Virus COVID-19 yang dimulai dari desa. Sesuai dengan informasi yang didapatkan telah tercatat sebanyak 1.559 kampung di tanggal 18 juni 2020 telah mendapatkan predikat Kampung Tangguh Semeru di wilayah Jawa Timur (Akbar, 2020). Program Kampung Tangguh tersebut dilaksanakan dengan berbasis komunitas warga sekitar dan melibatkan warga secara keseluruhan tanpa terkecuali (Imran, 2020). Program tersebut juga memberikan edukasi kepada masyarakat agar dapat meningkatkan kesadaran untuk dapat menanggulangi pandemi COVID-19 (Rekohadi, 2020). I Selain itu program tersebut telah diinisiasi oleh Kapolda Jatim serta mendapatkan dukungan penuh dari berbagai pihak seiring dengan perkembangan COVID-19 yang semakin dinamis. Oleh karena itu Pemerintah Daerah dituntut untuk dapat bergerak cepat dalam memberikan upaya kepada masyarakat dalam memutus mata rantai penyebaran Virus COVID-19 (Solichah, 2020). Keberhasilan program Kampung Tangguh tersebut terjadi karena adanya kolaborasi antara masyarakat, akademisi serta pemerintah. Adanya kolaborasi antar stakeholder tersebut sangat berperan terhadap pelaksanaan program Kampung Tangguh tersebut. Program tersebut juga memberikan edukasi atau sosialisasi kepada semua masyarakat untuk selalu menjaga jarak, tidak berkerumun serta tetap mentaati protokol kesehatan yang telah dibuat oleh pemerintah. Selain itu di beberapa desa yang telah menerapkan Program Kampung Tangguh menyediakan Posko yang menyediakan fasilitas berupa bantuan selama 24 jam untuk dapat membantu satgas dalam menjalankan tugasnya selama masa pandemi saat ini. Selain itu dalam menjalankan tugasnya, personil Satuan Tugas Kampung melibatkan seluruh elemen yang dimulai dari entitas yang terkecil yaitu Rukun Tetangga (RT), Karang Taruna serta warga lanjut usia yang telah mengemban tugas sebagai Satgas. Pembentukan Program Kampung Tangguh tersebut merupakan bentuk perhatian pemerintah terhadap suatu desa yang tercatat memiliki angka pasien positif yang tinggi. Sehingga program Kampung Tangguh dapat dijadikan sebagai benteng pertahanan dan keamanan di Indonesia.

Dengan diterapkannya konsep partisipasi dan kepedulian masyarakat dalam menanggulangi COVID-19, perbedaan yang ada tersebut dapat dijadikan sebagai suatu kesatuan dalam membangun ketahanan nasional secara substantif. Perlu diketahui bahwa program Kampung Tangguh juga dinilai memiliki keuntungan jika diterapkan dalam jangka waktu yang panjang maka akan dijadikan sebagai kekuatan tujuan strategis dalam menjaga persatuan dan kesatuan bangsa. Melalui Program Kampung Tangguh inilah masyarakat memiliki harapan besar agar dapat membantu memutus mata rantai penyebaran COVID-19 di Indonesia terutama di wilayah Jawa Timur. Sesuai dengan informasi yang didapatkan, Jawa Timur ditetapkan sebagai daerah yang memiliki kasus positif terbanyak. Oleh karena itu, adanya program tersebut diharapkan dapat merubah kebiasaan masyarakat untuk selalu mematuhi peraturan atau himbauan dari 
pemerintah. Hal tersebut karena masyarakat memiliki peran penting dalam membantu pemerintah menjalankan program Kampung Tangguh tersebut (Akbar, 2020). Program Kampung Tangguh telah diterapkan di beberapa daerah yang ada di Jawa Timur. Contoh nyata yang terjadi di sejumlah kelurahan di Kota Probolinggo. Terdapat beberapa kelurahan yang telah menerapkan program Kampung Tangguh di Probolinggo yaitu Kelurahan Tinonegaran, Kelurahan Mayangan, Kelurahan Pilang, dan Kelurahan Ketapang. Pada hari Minggu 31 Mei 2020, sejumlah Kampung Tangguh diluncurkan oleh Kapolres Probolinggo Kota yaitu AKBP Ambaryadi Wijaya (Arifin, 2020). Warga sangat antusias akan adanya program Kampung Tangguh. Masyarakat berharap dengan adanya program tersebut dapat meningkatkan kesadaran masyarakat untuk saling mengingatkan agar tetap mematuhi anjuran pemerintah dan dapat meminimalisir persebaran COVID-19.

Peran dan dinamika antar stakeholder yang berperan penuh dalam berjalannya Program Kampung Tangguh Semeru ini dapat terlihat mulai dari persiapan sebelum berjalannya program. Hal ini terlihat dari bagaimana awal pemerintah mengampanyekan program dengan harapan menyebarluasnya program unggulan ini dan mampu di implementasikan pada masingmasing desa. Melihat desa merupakan benteng pertahanan terakhir, peran antara pemerintah, akademisi, serta masyarakat diharapkan berjalan beriringan dalam menyukseskan Kampung Tangguh Semeru. Selain itu akademisi perlu memberikan kritik dan saran kepada pemerintah daerah dalam menetapkan desa-desa yang akan dituju karena masing- masing daerah berbeda-beda sehingga perlu mengamatan serta pemantauan terlebih dahulu agar penerapan Kampung Tangguh mampu terimplementasi secara baik. Masyarakat sangat antusias dan menerima kebijakan baru melalui program Kampung Tangguh Semeru. Keberhasilan program Kampung Tangguh ini akan berjalan sesuai keinginan apabila masyarakat juga berperan penuh dan aktif didalamnya sehinggamasyarakat mampu mengola hingga konsisten dengan segala bentuk aturan yang tertuang dan disepakati bersama sesuai dengan inovasi pada masing-masing desa.

Program Kampung Tangguh Benteng di Kota Probolinggo tersebut telah diapresiasi oleh Gubernur Jawa Timur Khofifah Indar Parawansa. Kampung Tangguh Semeru Benteng di Kelurahan / Kecamatan Mayangan Kota Probolinggo mendapatkan predikat Kampung Tangguh terbaik di Jawa Timur (Susilo, 2020). Program Kampung Tangguh Semeru telah diakui secara nasional dengan nama Kampung Tangguh Nusantara. Program tersebut dinilai lebih efektif dalam meningkatkan partisipasi masyarakat untuk saling bekerjasama dalam memutus mata rantai penyebaran Virus COVID-19. Oleh karena itu program Kampung Tangguh di Jawa Timur tersebut dijadikan sebagai percontohan Kampung Tangguh secara Nasional (Kurniawan, 2020). Kampung Tangguh Semeru Benteng di Keluruhan/Kecamatan Mayangan Kota Probolinggo memiliki inovasi yang sangat kaya karena tidak hanya menyiapkan bagaimana upaya dalam mendisiplinkan masyarakat tetapi juga menyiapkan solusi dalam menghadapi era normal yang berkelanjutan serta meningkatkan solidaritas yang dapat mempertahankan ketahanan dari level terbawah dengan cara saling

Tabel 1

Peran Stakeholder dalam Program Kampung Tangguh

\begin{tabular}{|c|c|c|}
\hline $\begin{array}{c}\text { Pelaku dalam } \\
\text { Kesuksesan Program } \\
\text { Kampung Tangguh }\end{array}$ & $\begin{array}{c}\text { Peran Serta Terhadap Program Kampung } \\
\text { Tangguh }\end{array}$ & Bentuk Kegiatan \\
\hline Pemerintah & $\begin{array}{ll}\text { - } & \text { Penerapan Kehidupan Baru (New Normal) } \\
\text { - } & \text { Penyediaan fasilitas }\end{array}$ & $\begin{array}{l}\text { - Pengawasan dan Pendampingan } \\
\text { Program Kampung Tangguh }\end{array}$ \\
\hline Akademisi & $\begin{array}{l}\text { - } \quad \text { Memberikan edukasi pada masyarakat } \\
\text { - } \quad \text { Pemanfaatan potensi desa }\end{array}$ & $\begin{array}{l}\text { - Memberikan solusi dan upaya pada } \\
\text { pemerintah }\end{array}$ \\
\hline Masyarakat & $\begin{array}{l}\text { Partisipasi pemerintah dalam membantu } \\
\text { akademisi dalam memutus mata rantai } \\
\text { penyebaran COVID-19 }\end{array}$ & $\begin{array}{l}\text { - Mematuhi protokol kesehatan dan } \\
\text { saling membantu antar sesama yang } \\
\text { membutuhkan } \\
\text { - } \\
\text { Membuat masker dan faceshield } \\
\text { secara mandiri }\end{array}$ \\
\hline
\end{tabular}

Sumber: Olahan Peneliti, 2020 
membantu tetangga sekitar yang membutuhkan (Susilo, 2020).

Faktor penghambat dan pendukung dalam kesuksesan program Kampung Tangguh dapat dilihat dari proses implementasi program memutus mata rantai penyebaran Virus COVID-19. Berjalannya Program Kampung Tangguh tentu perlu melewati beberapa tahapan agar diterima dan mampu diimplementasikan pada masyarakat luas. Selain itu dalam pelaksanaan Program Kampung Tangguh ini banyak terdapat hambatan yang menjadi sisi kendala keberlangsungan program antara lain, masih ada kampung yang belum sepenuhnya berhasil. Hal ini dikarenakan oleh masyarakat desa itu sendiri yang belum sepenuhnya menjalankan segala inovasi yang ada didalam Program Kampung Tangguh Semeru. Kemudian juga masih terdapat masyarakat yang memiliki tingkat kesadaran yang rendah akan pentingnya pencegahan virus COVID-19. Tingkat kesadaran masyarakat yang sulit dirubah inilah menimbulkan Program Kampung Tangguh Semeru belum berhasil dilaksanakan di beberapa desa. Akan tetapi juga banyak desa di Jawa Timur yang berhasil menerapkan Program Kampung Tangguh Semeru. Faktor pendorong berjalannya Program Kampung Tangguh Semeru di Jawa Timur yaitu banyak kalangan masyarakat yang juga berharap banyak terhadap kebijakan pemerintah. Inovasi Program Kampung Tangguh Semeru mampu menyadarkan banyak masyarakat akan hidup sehat serta mematuhi segala protokol kesehatan yang telah dianjurkan. Upaya pemerintah Jawa Timur yang terus mendorong serta mengkampanyekan program inimemungkinkan masyarakat mempercayai penuh keberhasilan Program Kampung Tangguh Semeru dengan kerjasama antar stakeholder. Kunci kesuksesan berjalannya Program Kampung Tangguh di Jawa Timur adalah bottom-up participation (partisipasi dari bawah) atau bentuk partisipasi masyarakat dalam menghadapi pandemi COVID-19 (Jatimprov, 2020).

Berbagai macam kebijakan yang telah diterbitkan oleh pemerintah pusatyang berkaitan dengan memutus mata rantai penyebaran Virus COVID-19 telah direalisasikan dengan baik oleh seluruh masyarakat di suatu desa. Pada dasarnya kesuksesan suatu kebijakan dapat dibuktikan dari kinerja serta laporan dari pelaksanaan program tersebut di suatu desa. Desa telah memiliki cara tersendiri dalam memitigasi penyebaran Virus COVID-19. Mitigasi bencana dilakukan dengan cara mengadakan sosialisasi atau edukasi kepada seluruh masyarakat terkait bagaimana tindakan yang dilakukan dalam menghadapi bencana, rambu-rambu rawan bencana, pembuatan jalur evaluasi, memberikan pendidikan dan pelatihan dalam meminimalisir dampak dari adanya bencana tersebut. Upaya dalam mengatasi suatu bencana terbagi menjadi dua yaitu upaya dalam hal fisik dan upaya dalam hal non fisik. Upaya fisik (structure mitigation) dapat diartikan sebagai upaya yang dilakukan untuk mengurangi resiko akibat adanya bencana dengan menurunkan kerentanan atau meningkatkan kemampuan dalam menghadapi ancaman bencana melalui pembangunan infrastruktur. Sedangkan upaya non fisik (non-structure mitigation) disebut sebagai upaya yang dilakukan dengan tujuan mengurangi resiko bencana dengan cara menurunkan kerentanan atau meningkatkan kemampuan untuk menghadapi ancaman terjadinya bencana yang dilakukan dengan cara meningkatkan kapasitas pemerintah dan masyarakat dalam menghadapi bencana (Sunarti, 2018).

Desa memiliki upaya tersendiri dalam memitigasi bencana dengan menggunakan cara penanggulangan berbasis komunitas. Penanggulangan berbasis komunitas (community-based disaster management) diartikan sebagai suatu pendekatan yang cenderung mendorong komunitas akar rumput dalam mengelolah resiko bencana di tingkat lokal yaitu dimulai dari desa. Dalam pelaksanaan mitigasi tersebut perlu adanya serangkaian rencana yang meliputi interpretasi ancaman dan resiko terhadap bencana yang sedang dihadapi. Selain itu mampu meminimalisir, memantau dan mengevaluasi kinerja stakeholder dalam penanggulangan becana (Habibullah, 2013). Permasalahan terkait pandemi yang saat ini sedang terjadi di Indonesia membuat masyarakat lokal tidak berdaya atau tidak memiliki kesempatan untuk berpendapat. Hal tersebut sedang terjadi di wilayah desa. Namun, jika upaya mitigasi tersebut lahir dari kesadaran sesuai dengan kapasitas komunitas di tingkat lokal serta prioritas yang dimiliki oleh suatu komunitas, upaya tersebut dapat terus menerus dilakukan secara berkelanjutan (Habibullah, 2013). Dapat disimpulkan bahwa pembahasan 
di atas saling berkaitan dengan peran desa yang dijadikan sebagai benteng pertahanan terakhir di level terendah yaitu desa. Selain itu pemerintah juga sedang berupaya untuk dapat meningkatkan kesadaran masyarakat untuk ikut serta dalam mensukseskan program tersebut. Selain itu pemerintah juga berupaya untuk dapat meningkatkan masyarakat di masa pandemi saat ini. Oleh karena itu masyarakat perlu diberikan pengetahuan, pemahaman, meningkatkan keterampilan, serta kepedulian masyarakat terhadap suatu hal yang berkaitan dengan kebencanaan atau pandemi. Sehingga masyarakat memiliki kesadaran untuk dapat bersikap dan mampu beradaptasi dengan lingkungan sekitar. Selain itu masyarakat juga dihimbau untuk dapat berpartisipasi dalam serangkaian kegiatan yang dilakukan secara aktif dalam meminimalisir terjadinya bencana dan cara mengatasi dampak jika akan terjadi bencana. Sosialiasi terkait cara memitigasi suatu bencana dapat dilakukan melalui berbagai teknis, namun yang terpenting edukasi tersebut mampu dipahami oleh semua masyarakat.

\section{Diskusi}

Kolaborasi antar stakeholder dalam penanggulangan COVID-19 sangat dibutuhkan. Melalui program Kampung Tangguh Semeru yang berbasis komunitas warga sekitar inilah bentuk kolaborasi dapat terwujud. Melalui program Kampung Tangguh, masyarakat dapat berpartisipasi secara langsung dalam upaya menekan angka positifCOVID-19 tanpa terkecuali yang dimulai dari entitas sosial yang paling kecil yaitu desa. Desa yang dijadikan sebagai benteng pertahanan terakhir harus mampu melakukan mitigasi bencana secara mandiri terutama terhadap penyebaran COVID-19 yang saat ini terjadi. Kunci kesuksesan berjalannya Program Kampung Tangguh di Jawa Timur adalah bottomup participation (partisipasi dari bawah) atau bentuk partisipasi masyarakat pada pemerintah dalam menghadapi pandemi COVID-19.

Pelaksanaan Program Kampung Tangguh Semeru menggunakan sistem pentahelix yaitu kolaborasi antara pemerintah, masyarakat, akademisi, pengusaha, dan media dalam mengatasi pandemi COVID-19. Melalui sistem pentahelix ini diharapkan dapat mengembangkan potensi desa dan memberikan manfaat untuk kesejahteraaan serta kemandirian masyarakat desa. Karena pada dasarnya dalam pelaksanaan program Kampung Tangguh tersebut memprioritaskan pada desa yang memiliki angka resiko penyebaran COVID-19 yang tinggi. Dengan adanya program Kampung Tangguh Semeru memberikan banyak manfaat untuk masyarakat dalam mengatasi permasalahan terkait kesehatan, sosial, ekonomi dan keamanan. Program Kampung Tangguh Semeru telah diadaptasi menjadi program dalam skala nasional dengan sebutan Kampung Tangguh Nusantara. Oleh karena itu, dengan adanya program kampung tangguh diharapkan dapat melawan penyebaran Virus COVID-19 yang dimulai dari lingkup terkecil yaitu dari desa dan warga sekitar (Megasari et al., 2020).

Oleh karena itu, dapat dilihat bahwa peran kolaborasi antar stakeholder yaitu pemerintah, masyarakat dan akademisi memiliki peranan yang sangat penting dalam perjalanan program Kampung Tangguh tersebut terutama di tengah kondisi saat ini. Jika terdapat salah satu pelaku tidak menjalankan perannya dengan baik, maka kebijakan yang telah dibuat tidak dapat direalisasikan dengan maksimal. Untuk itu pemerintah dituntut agar dapat mengendalikan informasi yang telah beredar agar informasi tersebut dapat dipertanggungjawabkan sesuai dengan fakta yang terjadi di lapangan. Selain itu dengan adanya media tersebut pemerintah dapat dengan mudah mengevaluasi serta mengontrol kegiatan masyarakat terutama dalam mematuhi aturan yang telah dianjurkan oleh pemerintah kepada semua masyarakat di masa pandemi saat ini.

\section{Kesimpulan}

Upaya paling tepat dalam memutus mata rantai penyebaran COVID-19 yang semakin masif adalah dengan cara kolaborasi antar stakeholder melalui program kampung Tangguh Semeru. Melalui kampung Tangguh inilah seluruh masyarakat ikut terlibat karena adanya komitmen dari masyarakat dalam memutus mata rantai penyebaran COVID-19 sangat dibutuhkan. Kebijakan sebaik apapun akan siasia jika tidak ada komitmen dari masyarakat. Untuk itu bekerjasama antara stakeholder dalam upaya memutus mata rantai penyebaran COVID-19 melalui program ini merupakan solusi terbaik karena dalam program Kampung Tangguh ini aparat memberikan sosialisasi kepada masyarakat untuk saling mengingatkan untuk menjahui kerumunan dan selalu 
menjaga jarak, serta mematuhi segala bentuk protokol kesehatan yang telah dianjurkan oleh pemerintah. Adanya pembentukan Program Kampung Tangguh tersebut dibuat untuk memberikan perhatian untuk wilayah yang berstatus zona merah.

Hasil dari penelitian yang dilakukan oleh peneliti lebih menonjol pada aspek ketangguhan desa, yaitu desa mampu menciptakan kepatuhan masyarakat terhadap aturan yang telah ditetapkan pemerintah serta mampu meningkatkan kesadaran masyarakat untuk saling mengingatkan dan bekerja sama untuk dapat menekan angka penyebaran Virus COVID-19. Strategi yang dilakukan oleh pemerintah desa dan masyarakat desa di dalam kampung tangguh tersebut adalah dengan cara memanfaatkan kemampuan masyarakat dalam mengelolah sumber daya yang ada untuk dapat dimanfaatkan sebagai pemenuhan kebutuhan masyarakat serta pembuatan handsanitizer dan menyediakan alat cuci tangan dan lain lain untuk dapat membantu keberhasilan pemerintah desa dan masyarakat dalam menekan angka penyebaran Virus COVID-19 (Wonok, 2018).

Desa yang dijadikan sebagai benteng pertahanan terakhir harus memiliki upaya dalam memitigasi bencana. Melalui program Kampung Tangguh Semeru inilah salah satu wujud dari upaya Desa sebagai benteng terakhir pertahanan dalam melakukan mitigasi terhadap penyebaran COVID-19 yang dilakukan mulai dari lingkup terkecil yaitu dari desa dan warga sekitar. Dalam aspek ini juga sangat berhubungan dengan entitas sosial. Oleh karena itu ketangguhan desa sebagai bentuk pertahanan terakhir sangat menentukan bagaimana sebuah kebijakan mampu terealisasikan dengan baik. Ketangguhan sosial yang mampu memanfaatkan keberagaman sosial guna saling menompang dan membangun solidaritas antar masyarakat desa. Eksistensi dari entitas sosial terhadap ketangguhan suatu desa akan diuji jika lingkungan tersebut menunjukan perubahan yang cukup signifikan serta berpengaruh terhadap masyarakat itu sendiri. Dalam pandemi COVID-19, banyakmasyarakat Indonesia mengalami defisit kreatifitas atau inovasi keberagaman sosial. Pandemi ini juga telah memberikan gambaran yang cukup jelas bagaimana sistem sosial bangsa Indonesia mampu bekerja, baik mulai dari ranah politik, sosial, ekonomi, maupun lingkungan. Oleh karena itu, penelitian yang menarik untuk selanjutnya yaitu mengenai mengapa sistem dan mekanisme mitigasi bencana harus berdasarkan asas lokalitas atau entitas sosial paling kecil.

\section{Referensi}

Akbar, M. (2020). Mengenal Konsep Kampung Tangguh untuk Tanggulangi COVID-19 di Jawa Timur. Jurnaba.Co. https:// jurnaba.co/mengenal-konsep-kampungtangguh-untuk-tanggulangi-COVID-19-dijawa-timur/

Al-Osail, A. M., Al-Wazzah, M. J. (2017). The history and epidemiology of Middle East respiratory syndrome corona virus. Multidisciplinary Respiratory Medicine, 12(1), pp 1-6. doi: doi.org/ 10.1186/ s40248-0170101-8

Anderson, R. M., Heesterbeek, H., Klinkenberg, D., \& Hollingsworth, T. D. (2020). How will country-based mitigation measures inf luence the co ur se of the C 0 V ID -19 epidemic? The Lancet, 395(10228), pp. 931-934. doi: doi.org/ 10.1016/ S0140- 6736(20)30567-5

Arifin, J. (2020) . Bentuk Kampung Tangguh di Probolinggo, ini Tujuannya. RadarBromo.Co.Id. https:// radarbromo. jawapos.com/ probolinggo/ 01/ 06/ 2020/ bentuk-kampung-tangguh-di-probolinggoini-tujuannya/

Azmi, F. (2020). Ini Detail Lengkap Kasus COVID-19 di Jawa Timur. DetikNews. https://news. detik.com/berita-jawa-timur/d-4989118/ ini-detail-lengkap-kasus-COVID-19-di-jawatimur

Barniat, Z. (2019). Otonomi Desa: Konsepsi Teoritis Dan. Jurnal Analisis Sosial Politik, 5(1), pp. 20-33.

Darmawan, D. (2019). Berita Negara Republik Indonesia. Journal of Chemical Information and Modeling, 53(9), pp. 1689-1699. doi: doi.org/ 10.1017/ CBO9781107415324.004

Erfinanto, E. (2020). Inovasi Polri Dalam Deretan Kampung Sehat dan Desa Pantang Mundur Lawan COVID-19. Liputan6. https:// www.liputan6.com/ regional/ read/4285216/inovasi-polri-dalamderetan-kampung-sehat-dan-desa-pantangmundur-lawan-COVID-19

Habibullah. (2013). Kebijakan Penanggulangan bencana Berbasis Komunitas : Kampung Siaga Bencana dan Desa/Kelurahan Tangguh Bencana. Informasi Kajian Permasalahan 
Yusrin Rahmawati, Farah Fadillah Anugrah, Erva Mutiara Hati, Ali Roziqin - Kampung Tangguh: Wujud Kolaborasi antar-Stakeholder dalam Merespons Pandemi COVID-19

Sosial Dan Usaha Kesejahteraan Sosial, 18(02), pp. 133-150.

Harihah, Z., Rizaldi, A. (2020). Merespon Nalar Kebijakan Negara Dalam Menangani Pandemi Covid 19 Di Indonesia. Jurnal Ekonomi Dan Kebijakan Publik Indonesia, 7(1), pp. 36-53. doi: doi.org/10.24815/ ekapi.v7i1.17370

Haryono, N. (2012). Jejaring untuk membangun kolaborasi sektor publik. Jurnal Jejaring Administrasi Publik, 1(4), pp. 47-53.

Imran, I. P. M. F. (2020). Kampung Tangguh Semeru. Polda Jatim. https://popcenterpoldajatim.com/

Jatimprov. (2020). Total ada 1.559 Kampung Tangguh Semeru di Jawa Timur. Jatimprov.Go.Id. http://jatimprov.go.id/ read/berita-pengumuman/total-ada-1-559kampung-tangguh-semeru-di-jawa-timur

Kurniawan, D. (2020). Kampung Tangguh di Jawa Timur Siap Jadi Percontohan Nasional. Liputan6. https://surabaya.liputan6.com/ read/4282106/kampung-tangguh-di-jawatimur-siap-jadi-percontohan-nasional

Mashuri, M. A., Aprilina, S. D., \& Nahdiyah, V. (2020). Peran Masyarakat Terhadap Pembangunan Ekonomi Berbasis Kampung Tangguh Sebagai Upaya Menekan Angka COVID-19 di RT 04 RW 14 Kelurahan Kalirungkut Kota Surabaya. Jurnal Manajemen \& Kewirausahaan, 5(2), pp. 141-156. ejournal.unira.ac.id/index.php/jurnal_ makro_manajemen/article/view/961

Megasari, R., Vidyastuti, A. N., Setya, E., Rahayu, P., Pangestu, O. (2020). Upaya Memutus Penyebaran Virus COVID-19 Melalui Pembentukan Kampung Tangguh Semeru Di Desa Tegalsari Kabupaten Malang. Jurnal Graha Pengabdian, 2(3), pp. 212-222.

Mukaromah, V. F. (2020). Melihat Peningkatan Kasus COVID-19 di Indonesia dari Bulan ke Bulan. Kompas. Com. https://www.kompas.com/tren/ $\mathrm{read} / 2020 / 09 / 01 / 200200165 /$ melihatpeningkatan-kasus-COVID-19-di-indonesiadari-bulan-ke-bulan

Phan, L. T et.al. (2020). Importation and Human-to-human transmissionof a Novel Coronavirus in Vietnam. The New England Journal of Medicine. 382 (9), pp. 872-874.

Rekohadi, D. (2020). Program Kampung
Tangguh Ala Polda Jatim Dikampanyekan, Siasat Hambat Pernularan COVID-19 di Jatim. SuryaMalang.Com. https://suryamalang. tribunnews.com/2020/05/16/programkampung-tangguh-ala-polda-jatimdikampanyekan-siasat-hambat-pernularanCOVID-19-di-jatim

Rivelino ., Ginting, A. H. (2020). Tata Kelola Kolaborative Dalam Kebijakan Publik Dari Perspektive Penanganan Covid -19 Dki Jakarta. Jurnal Politik Pemerintahan Dharma Praja, 13(1), pp. 36-51. doi: doi. org/ 10.33701/jppdp.v13i1.1027

Solichah, Z. (2020). Kota Probolinggo Memiliki 30 Kampung Tangguh Semeru. AntaraNews.Com. https://www.antaranews. com/berita/1559880/kota-probolinggomiliki-30-kampung-tangguh-semeru

Sunarti, V. (2018). Peranan Pendamping Desa Dalam Membentuk Masyarakat Sadar Bencana Sebagai Salah Satu Mitigasi Bencana. Jurnal Pendidikan, 4(2), pp. 166-182.

Susilo, A., Rumende, C. M., Pitoyo, C. W., Santoso, W. D., Yulianti, M., Herikurniawan, H., Sinto, R., Singh, G., Nainggolan, L., Nelwan, E. J., Chen, L. K., Widhani, A., Wijaya, E., Wicaksana, B., Maksum, M., Annisa, F., Jasirwan, C. O. M., \& Yunihastuti, E. (2020). Coronavirus Disease 2019: Tinjauan Literatur Terkini. Jurnal Penyakit Dalam Indonesia, 7(1), pp. 45-67.

Susilo, T. (2020). Kampung Tangguh di Kota Probolinggo Terbaik se-Jatim. Antaranews.Com. https://www.antaranews. com/berita/1559808/kh ofifah-kampun g-tangguh-di-kota-probolinggo-terbaik-s e-jatim

Telaumbanua, D. (2020). Urgensi Pembentukan Aturan Terkait Pencegahan COVID-19 di Indonesia. QALAMUNA: Jurnal Pendidikan, Sosial, Dan Agama, 12(01), pp. 59-70. doi.org/10.37680/qalamuna.v12i01.290

Ulya, H. N. (2020). Alternatif Strategi Penanganan Dampak ekonomi COVID-19 Pemerintah Daerah Jawa Timur pada Kawasan Agropolitan. El-Barka, 3(1), pp. 80-109.

Whitworth, J. (2020). COVID-19: A fast evolving pandemic. Transactions of the Royal Society of Tropical Medicine and Hygiene, 114(4), pp. 227-228. doi: doi.org/10.1093/trstmh/ traa 025

Wonok, G. R. J. (2018). Strategi Pemerintah Desa dalam Pencegahan Penyebaran Virus Corona 
(COVID-19) (Studi di Desa Mokobang Kecamatan Modoinding Kabupaten Minahasa Selatan). Journal of Materials Processing Technology, 9 (1), pp 1-8. 